\title{
Nickel Complex-Mediated Synthesis of Optically Active Wholly Aromatic Polyketones Bearing 2,2'-Dimethoxy-1,1'-binaphthyl-6,6'-ene Units
}

\author{
Katsuya Maeyama,,$^{1, \dagger}$ Kashiko Ogura, ${ }^{1}$ Akiko OKamoto, ${ }^{1}$ Kenji Ogino, ${ }^{2}$ \\ Hiromu SAITo, ${ }^{1}$ and Noriyuki YonEZAWA ${ }^{1, \dagger}$ \\ ${ }^{1}$ Department of Organic and Polymer Materials Chemistry, Graduate School, \\ Tokyo University of Agriculture and Technology, Koganei 184-8588, Japan \\ ${ }^{2}$ Graduate School of Bio-Applications and Systems Engineering, \\ Tokyo University of Agriculture and Technology, Koganei 184-8588, Japan
}

(Received March 11, 2005; Accepted June 9, 2005; Published October 15, 2005)

\begin{abstract}
Bis(chlorobenzoyl)-2,2'-dimethoxy-1,1'-binaphthyls $\mathbf{2 a}$ and $\mathbf{2 b}$ are prepared via $\mathrm{P}_{2} \mathrm{O}_{5}-\mathrm{MsOH}^{\prime}$ mediated regioselective diaroylation of 2,2'-dimethoxy-1,1'-binaphthyl (1). $\mathrm{NiBr}_{2} / \mathrm{Zn}$-mediated aromatic coupling polymerization of 6,6'-bis(chlorobenzoyl)-2,2'-dimethoxy-1,1'-binaphthyls 2 yields the corresponding wholly aromatic polyketones. When optically active bis(chlorobenzoylated) binaphthyls (2) are employed, optically active wholly aromatic polyketones $\mathbf{3}$ with large specific rotations, excellent thermal resistance, and excellent solubility to organic solvents are obtained. [DOI 10.1295/polymj.37.736]

KEY WORDS 2,2'-Dimethoxybinaphthyl / Nickel Complex-Mediated Aromatic Coupling Polymerization / Wholly Aromatic Polyketone / Excellent Solubility / Optically Active Polyketones /
\end{abstract}

There have been a lot of reports on aromatic polyketones, which have attracted much attention for their excellent physical and chemical resistance. ${ }^{1-8}$ On the other hand, there have been only a few reports on wholly aromatic polyketones, i.e., aromatic polyketones without ether bonds in the main chains. ${ }^{8-13}$ Electrophilic aromatic aroylation reaction ${ }^{8}$ and aromatic coupling reaction ${ }^{9-12}$ are presumed to be the useful protocols for syntheses of wholly aromatic polyketones.

We have already reported that $\mathrm{AlCl}_{3}$-mediated Friedel-Crafts type polymerization ${ }^{14-16}$ and phosphorus oxide-methanesulfonic acid mixture $\left(\mathrm{P}_{2} \mathrm{O}_{5}-\right.$ $\mathrm{MsOH})$ mediated direct condensation polymerization $^{17}$ using 2,2'-dimethoxybiphenyl proceed with sustainable reactivity and high regioselectivity at 5,5'-positions, giving wholly aromatic polyketones with high-molecular-weights. In addition, we have also succeeded in the synthesis of 2,2'-dimethoxy5,5'-biphenylene-containing wholly aromatic polyketones via $\mathrm{NiBr}_{2} / \mathrm{Zn}$-mediated aromatic coupling polymerization. ${ }^{18-20}$

As the application of wholly aromatic polyketones, we planned the synthesis of wholly aromatic polyketones bearing 2,2'-dimethoxy-1,1'-binaphthyl-6,6'ene units instead of 2,2'-dimethoxybiphenylene ones. Introduction of aromatic units with large dihedral angle between two naphthalene rings, e.g. 2,2'-dialkoxy$1,1^{\prime}$-binaphthylene units, probably weakens intermo- lecular interaction such as $\pi, \pi$-stacking during polymerization, which will realize further sustainable polymerization. In addition, the polymer skeletons have axial chirality and will be widely applied as ligands for asymmetric transition metal catalysts. ${ }^{21}$ Introduction of optically active ligands on the chemical-resistant polymer backbones would be effective for creation of a novel type of polymeric ligands. There have been several reports on the syntheses of polymers such as polyarylenes, polycarbonates, polyamides, and polyimides containing 2,2'-disubstituted $1,1^{\prime}$-binaphthylene units. ${ }^{22-28}$ However, there have been no reports on wholly aromatic polyketones containing axially chiral units such as $2,2^{\prime}$-dimethoxy$1,1^{\prime}$-binaphthylene units in main chains.

Preliminary, we have reported the regioselective diaroylation ${ }^{29}$ of $2,2^{\prime}$-dimethoxy-1, $1^{\prime}$-binaphthyl proceeds at 6,6'-positions with the aid of $\mathrm{P}_{2} \mathrm{O}_{5}-\mathrm{MsOH}$ as a condensing reagent and a solvent. This motivated us to synthesize $2,2^{\prime}$-dimethoxy-1,1'-binaphthylenecontaining wholly aromatic polyketones.

In this paper, we would like to report $\mathrm{NiBr}_{2} / \mathrm{Zn}$ mediated aromatic coupling polymerization of $6,6^{\prime}-$ bis(chlorobenzoylated) 2,2'-dimethoxy-1,1'-binaphthyls, which are prepared through regioselective bis(chlorobenzoylation) of 2,2'-dimethoxy-1,1'-binaphthyl.

\footnotetext{
${ }^{\dagger}$ To whom correspondence should be addressed (Tel: +81-42-388-7475/7053, Fax: +81-42-388-7291, E-mail: maeyama@cc.tuat.ac.jp/ yonezawa@cc.tuat.ac.jp).
} 


\section{EXPERIMENTAL}

\section{General}

${ }^{1} \mathrm{H}$ NMR spectra were recorded on a JEOL JNMAL300 (300 MHz). Chemical shifts are expressed in ppm relative to internal standard of $\mathrm{Me}_{4} \mathrm{Si}(\delta, 0.00)$. ${ }^{13} \mathrm{C}$ NMR spectra were recorded on a JEOL JNMAL300 $(75 \mathrm{MHz})$. Chemical shifts are expressed in ppm relative to internal standard of $\mathrm{CDCl}_{3}(\delta, 77.0)$. IR measurement was recorded on a JEOL FT/IR5300. Specific rotations were measured in $\mathrm{CHCl}_{3}$ $\left(\mathrm{c}=0.05 \mathrm{~g} \mathrm{dL}^{-1}\right)$ using a JASCO DIP-1000 digital polarimeter.

Gel permeation chromatography (GPC) measurements were carried out at a flow rate of $1.0 \mathrm{~mL} \mathrm{~min}^{-1}$ at $40^{\circ} \mathrm{C}$ using $\mathrm{CHCl}_{3}$ as an eluent on a Shimadzu SPD$6 \mathrm{~A}$ equipped with a UV detector $(300 \mathrm{~nm})$ and a Shodex GPC KD-806M column. Inherent viscosities $\left(\eta_{\text {inh }}\right)$ were determined in a concentrated $\mathrm{H}_{2} \mathrm{SO}_{4}(0.3$ $\mathrm{g} \mathrm{dL}^{-1}$ ) solution at $30^{\circ} \mathrm{C}$ using an Ostwald viscometer. Glass transition temperatures $\left(T_{\mathrm{g}} \mathrm{s}\right)$ were determined on the basis of DSC curves. DSC curves were recorded on a Rigaku DSC-8230 differential scanning calorimeter with a heating rate of $10 \mathrm{~K} \mathrm{~min}^{-1}$ under nitrogen. Thermal degradation temperature $\left(T_{\mathrm{d}}\right)$ was determined on the basis of a TGA thermogram. The TGA thermogram was recorded on a Rigaku TG-8120 thermogravimeter with a heating rate of $10 \mathrm{~K} \mathrm{~min}^{-1}$.

$\mathrm{P}_{2} \mathrm{O}_{5}-\mathrm{MsOH}$ was prepared according to Eaton's procedure. ${ }^{30}$

Preparation of Bis(chlorobenzoylated) 2,2'-Dimethoxy-1,1'-binaphthyl (2)

To a reaction mixture of 4- or 3-chlorobenzoic acid $(1.5 \mathrm{mmol})$ and 2,2'-dimethoxy-1-1'-binaphthyl (1, $0.50 \mathrm{mmol}$ ) placed in a round flask, $\mathrm{P}_{2} \mathrm{O}_{5}-\mathrm{MsOH}$ $(1.5 \mathrm{~mL})$ was added and the reaction mixture was stirred at $60^{\circ} \mathrm{C}$ for $24 \mathrm{~h}$. Water was added to the reaction mixture and the aqueous mixture was neutralized with aqueous sodium hydroxide and extracted with ether for three times. The combined extracts were washed with aqueous $0.1 \mathrm{M}$ potassium hydroxide and brine successively and dried over anhydrous magnesium sulfate. After removal of solvent, the residue was purified by recrystalization from ethanol/chloroform to give the pure product as a dark brown solid.

6, 6'-Bis(4-chlorobenzoyl)-2,2'-dimethoxy-1, $1^{\prime}$-binaphthyl (2a). $\mathrm{mp} 214.5-215^{\circ} \mathrm{C}\left(\mathrm{CHCl}_{3} /\right.$ ethanol). IR $v(\mathrm{KBr}): 1651,1612,1478,1092 \mathrm{~cm}^{-1} .{ }^{1} \mathrm{H}$ NMR $\delta\left(\mathrm{CDCl}_{3}\right): 3.83(6 \mathrm{H}, \mathrm{s}), 7.18(2 \mathrm{H}, \mathrm{d}, J=8.4 \mathrm{~Hz}), 7.48$ $(4 \mathrm{H}, \mathrm{d}, J=8.7 \mathrm{~Hz}), 7.54(2 \mathrm{H}, \mathrm{d}, J=8.4 \mathrm{~Hz}), 7.69$ $(2 \mathrm{H}, \mathrm{dd}, J=1.8,8.4 \mathrm{~Hz}), 7.81(4 \mathrm{H}, \mathrm{d}, J=8.7 \mathrm{~Hz})$, $8.09(2 \mathrm{H}, \mathrm{d}, J=8.4 \mathrm{~Hz}), 8.29(2 \mathrm{H}, \mathrm{d}, J=1.8 \mathrm{~Hz})$ ppm. ${ }^{13} \mathrm{C}$ NMR $\delta \quad\left(\mathrm{CDCl}_{3}\right): 56.5, \quad 114.4,118.7$,
$125.4,126.2,127.7,128.6,131.4,131.6,132.2$, 132.5, 136.0, 136.4, 138.5, 157.1, 195.2 ppm. Anal. Calcd. for $\mathrm{C}_{36} \mathrm{H}_{24} \mathrm{Cl}_{2} \mathrm{O}_{4}: \mathrm{C}, 73.10 \%$; $\mathrm{H}, 4.09 \%$. Found: C, $72.93 \%$; H, $4.25 \%$.

6,6'-Bis(3-chlorobenzoyl)-2,2' -dimethoxy-1,1'-binaphthyl (2b). $\mathrm{mp} 131.5-133.5^{\circ} \mathrm{C}\left(\mathrm{CHCl}_{3} /\right.$ ethanol $)$. IR $v(\mathrm{KBr}): 1655,1471,1064 \mathrm{~cm}^{-1}$. ${ }^{1} \mathrm{H}$ NMR $\delta$ $\left(\mathrm{CDCl}_{3}\right): 3.83(6 \mathrm{H}, \mathrm{s}), 7.19(2 \mathrm{H}, \mathrm{d}, J=8.4 \mathrm{~Hz}), 7.45$ $(2 \mathrm{H}, \mathrm{t}, J=8.4 \mathrm{~Hz}), 7.55(2 \mathrm{H}, \mathrm{d}, J=8.4 \mathrm{~Hz}), 7.57$ $(2 \mathrm{H}, \mathrm{d}, J=8.7 \mathrm{~Hz}), 7.70(2 \mathrm{H}, \mathrm{dd}, J=8.7,1.5 \mathrm{~Hz})$, $7.72(2 \mathrm{H}, \mathrm{d}, J=8.7 \mathrm{~Hz}), 7.83(2 \mathrm{H}, \mathrm{t}, J=1.5 \mathrm{~Hz})$, $8.11(2 \mathrm{H}, \mathrm{d}, J=8.7 \mathrm{~Hz}), 8.31(2 \mathrm{H}, \mathrm{d}, J=1.5 \mathrm{~Hz})$ ppm. ${ }^{13} \mathrm{C}$ NMR $\delta\left(\mathrm{CDCl}_{3}\right): 56.6,114.4,125.5,126.2$, 127.7, 128.0, 129.6, 129.8, 131.7, 132.0, 132.7, 134.5, 136.2, 139.9, 140.2, 148.4, 157.2, 198.8 ppm. Anal. Calcd. for $\mathrm{C}_{36} \mathrm{H}_{24} \mathrm{Cl}_{2} \mathrm{O}_{4}: \mathrm{C}, 73.10 \%$; $\mathrm{H}, 4.09 \%$. Found: C, $72.82 \%$; H, $4.28 \%$.

\section{$\mathrm{NiBr}_{2} / \mathrm{Zn}$-Mediated Aromatic Coupling Polymeriza- tion}

6,6'-Bis(4-chlorobenzoyl)-2,2'-dimethoxy-1,1'-binaphthyl (2a, $0.4 \mathrm{mmol}, 236 \mathrm{mg}), \mathrm{NiBr}_{2}(0.2 \mathrm{mmol}$, $43.7 \mathrm{mg})$, triphenylphosphine $(0.4 \mathrm{mmol}, 105 \mathrm{mg})$, 2,2'-bipyridyl ( $0.2 \mathrm{mmol}, 31.2 \mathrm{mg})$, and $\mathrm{Zn}(1.2 \mathrm{mmol}$, $78.5 \mathrm{mg}$ ) were placed in a two-necked round flask and to this mixture, freshly distilled DMAc $(0.8 \mathrm{~mL})$ was added via a syringe. The reaction mixture was stirred at $100^{\circ} \mathrm{C}$ for $2 \mathrm{~h}$. The mixture was diluted with DMAc and the solution was poured dropwise into a hydrochloric acid/methanol solution ( $2 \mathrm{M}$ ) with stirring to separate out a solid. The solid was filtrated and washed with methanol. The precipitates were dried under reduced pressure at $80^{\circ} \mathrm{C}$ to give polymer 3a. Polymer 3b was synthesized according to this procedure.

Polymer 3a. IR v (KBr): 1651, 1616, $1477 \mathrm{~cm}^{-1}$. ${ }^{1} \mathrm{H}$ NMR $\delta\left(\mathrm{CDCl}_{3}\right): 3.83(6 \mathrm{H}$, pseudo s), $7.20(2 \mathrm{H}$, pseudo d, $J=9.0 \mathrm{~Hz}), 7.55(2 \mathrm{H}$, pseudo d, $J=9.0$ $\mathrm{Hz}), 7.76-7.81(6 \mathrm{H}, \mathrm{m}), 7.98(4 \mathrm{H}$, pseudo d, $J=9.0$ $\mathrm{Hz}), 8.11(2 \mathrm{H}$, pseudo d, $J=9.0 \mathrm{~Hz}), 8.38(2 \mathrm{H}$, pseudo s) $\mathrm{ppm} .{ }^{13} \mathrm{C}$ NMR $\delta\left(\mathrm{CDCl}_{3}\right): 56.6,114.4,118.7$, 125.4, 126.4, 127.2, 127.7, 130.7, 131.6, 132.5, 132.6, 136.0, 137.5, 143.6, 157.1, 196.0 ppm. Anal. Calcd. for $\left(\mathrm{C}_{36} \mathrm{H}_{24} \mathrm{O}_{4}\right)_{n}$ : $\mathrm{C}, 83.06 \% ; \mathrm{H}, 4.65 \%$. Found: $\mathrm{C}$, $82.58 \%$; H, $4.61 \%$.

Polymer 3b. IR v (KBr): $1655,1616,1475 \mathrm{~cm}^{-1}$. ${ }^{1} \mathrm{H}$ NMR $\delta\left(\mathrm{CDCl}_{3}\right): 3.78(6 \mathrm{H}$, pseudo s), $7.20(2 \mathrm{H}$, pseudo d, $J=9.0 \mathrm{~Hz}$ ), $7.47(2 \mathrm{H}$, pseudo d, $J=11.0$ $\mathrm{Hz}), 7.57(2 \mathrm{H}$, pseudo d, $J=9.0 \mathrm{~Hz}), 7.75(2 \mathrm{H}$, pseudo d, $J=9.0 \mathrm{~Hz}), 7.83(4 \mathrm{H}$, pseudo t, $J=11.0 \mathrm{~Hz})$, $8.04(2 \mathrm{H}$, pseudo d, $J=9.0 \mathrm{~Hz}), 8.11(2 \mathrm{H}$, pseudo s), 8.35 (2H, pseudo s) ppm. ${ }^{13} \mathrm{C}$ NMR $\delta\left(\mathrm{CDCl}_{3}\right)$ : $56.5,114.3,118.7,125.4,126.4,127.7,128.5,128.9$, 129.3, 130.8, 131.6, 132.3, 132.8, 136.0, 138.9, 140.5, 157.1, $196.2 \mathrm{ppm}$. Anal. Calcd. for $\left(\mathrm{C}_{36} \mathrm{H}_{24} \mathrm{O}_{4}\right)_{n}$ : C, $83.06 \%$; H, 4.65\%. Found: C, 82.65\%; H, 4.78\%. 
Table I. Bis(chlorobenzoylation) of 2,2'-dimethoxy-1, $1^{\prime}$-binaphthyl (1)

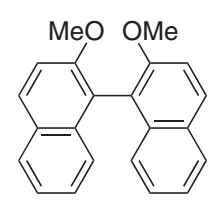

1
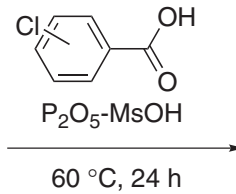

$60^{\circ} \mathrm{C}, 24 \mathrm{~h}$

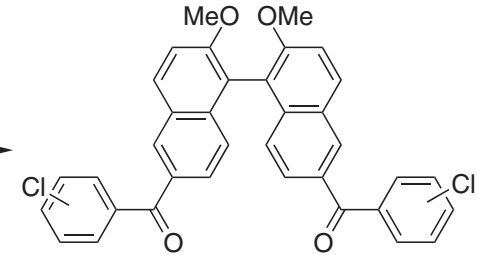

$2 \mathbf{a}\left(4,4^{\prime}-\mathrm{Cl}\right)$

$2 b\left(3,3^{\prime}-C l\right)$

\begin{tabular}{cccc}
\hline Run & Chlorobenzoic acid & Time $/ \mathrm{h}$ & Yield $/ \%$ \\
\hline 1 & $4-\mathrm{Cl}$ & 24 & 90 \\
2 & $3-\mathrm{Cl}$ & 4 & 86
\end{tabular}

Reaction conditions: 2,2'-dimethoxy-1,1'-binaphthyl (1), $0.5 \mathrm{mmol}$; chlorobenzoic acid, $1.5 \mathrm{mmol} ; \mathrm{P}_{2} \mathrm{O}_{5}-\mathrm{MsOH}, 1.5 \mathrm{~mL}$.

Table II. $\mathrm{NiBr}_{2} / \mathrm{Zn}$-mediated aromatic coupling polymerization of 6,6'-bis(4-chlorobenzoyl)2,2'-dimethoxy-1,1'-binaphthyl (2a)

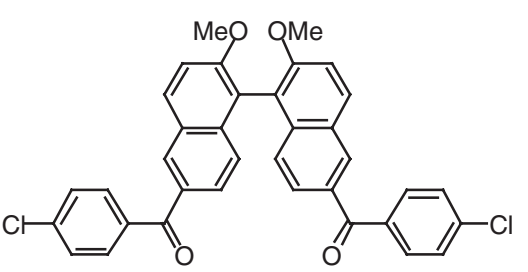

$2 \mathbf{a}$

\begin{tabular}{clccccc}
\hline Run & Solvent & Temp. $/{ }^{\circ} \mathrm{C}$ & Time $/ \mathrm{h}$ & Yield $/ \%$ & $\eta_{\text {inh }} / \mathrm{dLg}^{-1 \mathrm{a}}$ & Film $^{\mathrm{b}}$ \\
\hline 1 & THF & reflux & 2 & 0 & - & - \\
2 & DMAc & 100 & 2 & 24 & 0.37 & - \\
3 & NMP & 100 & 2 & 91 & 0.18 & - \\
3 & DMF & 100 & 2 & 98 & $0.59^{\mathrm{c}}$ & + \\
4 & & 120 & 2 & 98 & 0.26 & - \\
5 & & 80 & 2 & 91 & 0.13 & - \\
6 & & 100 & 1 & 98 & 0.39 & - \\
7 & & & 4 & 88 & 0.18 & - \\
\hline
\end{tabular}

Reaction conditions: 6,6'-bis(4-chlorobenzoyl)-2,2'-dimethoxy-1,1'-binaphthyl (2a), $0.4 \mathrm{mmol}$; $\mathrm{NiBr}_{2}, 0.2 \mathrm{mmol} ; \mathrm{NiBr}_{2} / \mathrm{PPh}_{3} /$ bipyridyl $=1 / 2 / 1$; Solvent, $0.8 \mathrm{~mL} ; \mathrm{N}_{2}$ atmosphere. ${ }^{a}$ Inherent viscosity was determined in a conc. $\mathrm{H}_{2} \mathrm{SO}_{4}$ solution $(0.3 \mathrm{~g} / \mathrm{dL})$ at $30^{\circ} \mathrm{C} .{ }^{\mathrm{b}}+$, obtained as a flexible film. - failure in film forming. ${ }^{\mathrm{c}} M_{\mathrm{n}}$ was determined as 12,000 by GPC calculation (Column: Shodex, GPC KD-806M. Eluent: $\mathrm{CHCl}_{3}$, UV detector: $300 \mathrm{~nm}$ ).

\section{RESULTS AND DISCUSSION}

Preparation of 6,6'-Bis(chlorobenzoylated) 2,2'-Dimethoxy-1,1'-binaphthyls $2 \boldsymbol{2 a}, \boldsymbol{b}$

When 3 equimolar amounts of $p$ - or $m$-chlorobenzoic acid was treated with $2,2^{\prime}$-dimethoxy-1, $1^{\prime}$-binaphthyl (1) in the presence of $\mathrm{P}_{2} \mathrm{O}_{5}-\mathrm{MsOH}$, regioselective diaroylation reaction proceeded to afford $6,6^{\prime}$ bis(chlorobenzoyl)-2,2' -dimethoxy-1,1'-binaphthyls (2), the monomers for nucleophilic aromatic substitution polymerization, in good yields. Two methoxy groups situated at 2,2'-positions probably enhance the reactivity and regioselectivity at 6,6'-positions sterically and electrically.
$\mathrm{NiBr}_{2} / \mathrm{Zn}$-Mediated Aromatic Coupling Polymerization

Bis(4-chlorobenzoyl)-2,2'-dimethoxy-1,1'-binaphthyl (2a) was treated with $50 \mathrm{~mol} \%$ of $\mathrm{NiBr}_{2}, 310$ mol \% of $\mathrm{Zn}, 100 \mathrm{~mol} \%$ of $\mathrm{PPh}_{3}$, and $50 \mathrm{~mol} \%$ of 2,2'-bipyridyl in several solvents.

Table II shows the results of the polymerization. The degree of polymerization was estimated by measurement of inherent viscosity in a concentrated $\mathrm{H}_{2} \mathrm{SO}_{4}$ solution. Among solvents screened, DMF was the most suitable for sustainable polymerization. In particular, when the reaction was performed at $100^{\circ} \mathrm{C}$ for $2 \mathrm{~h}$, the highest molecular weight polyketone was obtained. In addition, there was no signal assignable to protons of chlorobenzoyl groups in the ${ }^{1} \mathrm{H}$ NMR 


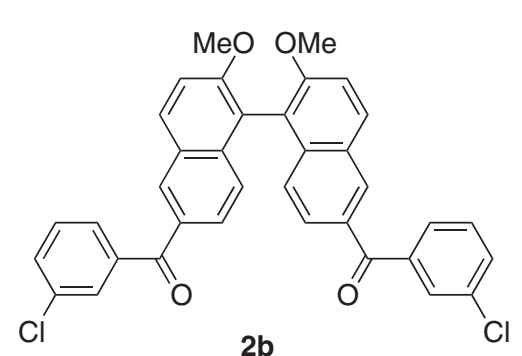

$2 b$

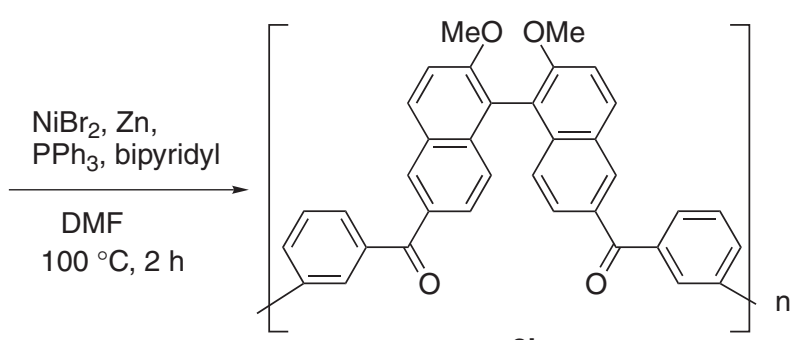

$3 \mathbf{b}$

$98 \%$ yield. $\eta_{\text {inh }}=0.22 \mathrm{dL} / \mathrm{g}\left(\mathrm{H}_{2} \mathrm{SO}_{4}\right)$ $M_{\mathrm{n}}=9100$

Scheme 1.

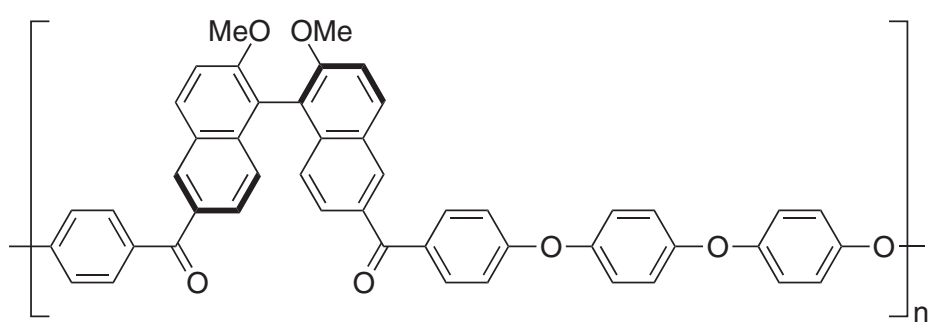

(S)-4

Figure 1. Structure of optically active poly(ether ketone) (S)-4.

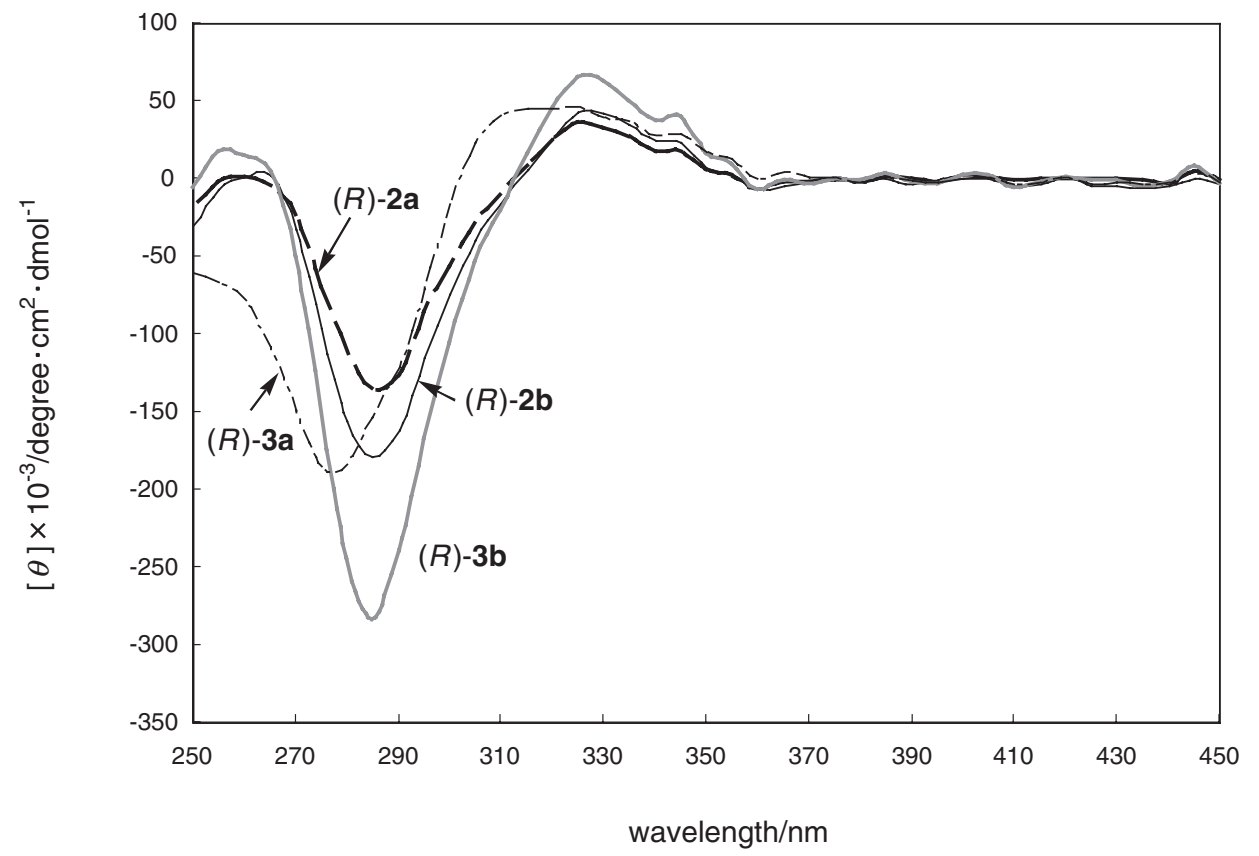

Figure 2. CD spectra of polyketones $(R)-\mathbf{3 a} / \mathbf{3 b}$ and monomer $(R)-\mathbf{2 a} / \mathbf{2 b}$.

spectra of these polyketones.

Polymerization of regioisomeric monomer $\mathbf{2 b}$ was also performed under the optimized reaction conditions in the polymerization of monomer 2a. In the same manner, polymerization proceeds to give the corresponding wholly aromatic polyketone $(\mathbf{3 b})$.

Next, optically active wholly aromatic polyketones $(R)$-3a and $(R)$-3b were prepared as the same as usual from $(R)-2,2^{\prime}$-dimethoxy-1,1'-binaphthyl. Specific rotations and circular dichroism (CD) spectra of polyketones $(R)-\mathbf{3 a}$ and $(R)-\mathbf{3 b}$ are shown in Table III and Figure 2.

The resulting polyketones $(R)-\mathbf{3 a}$ and $(R)-\mathbf{3 b}$ show much larger specific rotations than monomers $(R)$ $\mathbf{2 a} / \mathbf{2 b}$ and aromatic poly(ether ketone) $\mathbf{4}$, which is synthesized via nucleophilic aromatic substitution polymerization of (S)-6,6'-bis(4-fluorobenzoyl)-2,2'dimethoxy-1,1'-binaphthyl with $4,4^{\prime}$-oxybiphenol. ${ }^{31}$ 
Table III. Specific rotations and thermal properties of optically active wholly aromatic polyketones $(R)-\mathbf{3 a}$,

$(R)-3 \mathbf{b}$ and poly(ether ketone) (S)-4

\begin{tabular}{ccccc}
\hline Run & Polyketone & {$[\alpha]_{\mathrm{D}}{ }^{25} / \mathrm{deg}^{\mathrm{a}}$} & $T_{\mathrm{g}} /{ }^{\circ} \mathrm{C}$ & $T_{\mathrm{d}} /{ }^{\circ} \mathrm{C}^{\mathrm{b}}$ \\
\hline 1 & $(R)-\mathbf{3 a}$ & $-427^{\mathrm{c}}$ & 167 & 458 \\
2 & $(R)-\mathbf{3 b}$ & $-346^{\mathrm{d}}$ & 160 & 416 \\
3 & $(S)-\mathbf{4}$ & +31 & 170 & 404 \\
\hline
\end{tabular}

${ }^{\mathrm{a}}$ Optical rotations were measured in $\mathrm{CHCl}_{3}(\mathrm{c}=0.05 \mathrm{~g} / \mathrm{dL})$. ${ }^{\mathrm{b}}$ Temperature where a $10 \mathrm{wt} \%$ loss was recorded by TG. ${ }^{\mathrm{c}}$ Monomer $(R)-\mathbf{2 a} ;[\alpha]:-41^{\circ}$. ${ }^{\mathrm{d}} \operatorname{Monomer}(R)-\mathbf{2 b} ;[\alpha]:-37^{\circ}$.

Specific rotation of polyketone $\mathbf{3 a}$ is larger than that of polyketone $\mathbf{3 b}$, which is due to high rigidity of $p, p$ biphenylene units compared with $m, m$-biphenylene ones, presumably. CD spectra of polyketones $\mathbf{3}$ show an increase in intensity of the Cotton effects compared with monomers $\mathbf{2}$. In addition, $(S)$ - and $(R)-3$ exhibit mirror-image Cotton effects. These results probably suggest that wholly aromatic polyketones $\mathbf{3}$ hold regular secondary structures such as helix on the basis of introduction of rigid polymer backbones, i.e., exclusion of flexible ether bonds from main chains.

Thermal behaviors of the resulting wholly aromatic polyketones (3) are examined. DSC curve shows that glass transition temperature of polyketone $\mathbf{3 a}$ is $167^{\circ} \mathrm{C}$ and that of polyketone $3 \mathrm{~b}$ is $160^{\circ} \mathrm{C}$. $T_{\mathrm{g}}$ values of polyketones 3 are lower by $c a .50^{\circ} \mathrm{C}$ than those of wholly aromatic polyketones containing $2,2^{\prime}-d i$ methoxybiphenylene units. ${ }^{14-17}$ This is probably because 2,2'-dimethoxy-1,1'-binaphthylene units have weaker intermolecular interaction on the basis of larger dihedral angle between biaryls than 2,2'dimethoxybiphenylene ones. The TGA thermogram shows that the resulting polyketones keep the weight up to $c a .400{ }^{\circ} \mathrm{C}$ and they begin to decompose gradually. The thermal behavior is similar to those of wholly aromatic polyketones containing 2,2'-dimethoxybiphenylene units. This similarity suggests that thermal degradation of these polyketones $\mathbf{3}$ and $\mathbf{4}$ occurs motivated by cleavage of $\mathrm{sp}^{3}$ carbon-oxygen bonds of methoxy groups.

\section{CONCLUSIONS}

6,6'-Bis(chlorobenzoyl)-2,2'-dimethoxy-1,1'-binaphthyls 2 were prepared in good yields with the aid of $\mathrm{P}_{2} \mathrm{O}_{5}-\mathrm{MsOH}$. $\mathrm{NiBr}_{2} / \mathrm{Zn}$-mediated aromatic coupling polymerization yielded high molecular weight polyketones 3. Application of optically active 2,2'-dimethoxy-1,1'-binaphthyls enabled us to formulate a novel type of optically active wholly aromatic polyketones with excellent thermal resistance, and excellent solubility to organic solvents.
Acknowledgment. This work was supported financially by Mukai Science and Technology Foundation.

\section{REFERENCES}

1. T. E. Attwood, P. C. Dawson, J. L. Freeman, L. R. J. Hoy, J. B. Rose, and P. A. Staniland, Polymer, 22, 1096 (1981).

2. M. J. Mullins and E. P. Woo, J. Macromol. Sci., Rev. Macromol. Chem., 27, 313 (1987).

3. P. A. Staniland, "Comprehensive Polymer Science" 2 ed, G. C. Eastmond, A. Ledwith, S. Russo, and P. Sigwalt, Ed., Pergamon Press, Oxford, U.K., 1989, Vol. 5, p 483.

4. M. Ueda, Synlett, 605 (1992).

5. N. Yonezawa, J. Synth. Org. Chem. Jpn., 53, 172 (1995).

6. M. Ueda and M. Sato, Macromolecules, 20, 2675 (1987).

7. M. Ueda and M. Oda, Polym. J., 21, 673 (1989).

8. M. G. Zolotukhin H. M. Colquhoun, L. G. Sestiaa, D. R. Rueda, and D. Flot, Macromolecules, 36, 4766 (2003).

9. M. Bochmann and K. Kelley, J. Chem. Soc., Chem. Commun., 532 (1989).

10. M. Rahahn, A.-D. Schlueter, and G. Wagner, Makromol. Chem., Rapid Commun., 11, 535 (1990).

11. J. S. Moore, Makromol. Chem., Rapid Commun., 13, 91 (1992).

12. M. Bochmann and J. Lu, J. Polym. Sci., Part A: Polym. Chem., 32, 2493 (1994).

13. K. Maeyama, J. Synth. Org. Chem. Jpn., 63, 616 (2005).

14. N. Yonezawa, S. Miyata, T. Nakamura, S. Mori, Y. Ueha, and R. Katakai, Macromolecules, 26, 5262 (1993).

15. N. Yonezawa, T. Namie, T. Ikezaki, T. Hino, H. Nakamura, Y. Tokita, and R. Katakai, React. Funct. Polym., 20, 261 (1996).

16. N. Yonezawa, S. Mori, S. Miyata, Y. Ueha-Anyashiki, S. M. Wu, and K. Maeyama, Polym. J., 35, 998 (2003).

17. N. Yonezawa, A. Kameda, T. Jobashi, S. Maruyama, and K. Maeyama, Polym. J., 36, 345 (2004).

18. N. Yonezawa, T. Ikezaki, H. Nakamura, and K. Maeyama, Macromolecules, 33, 8125 (2000).

19. K. Maeyama, S. Sekimura, M. Takano, T. Hino, and N. Yonezawa, React. Funct. Polym., 58, 111 (2004).

20. K. Maeyama, T. Kinuno, T. Jobashi, and N. Yonezawa, React. Funct. Polym., 59, 155 (2004).

21. R. Noyori, Chem. Soc. Rev., 18, 187 (1989).

22. Q. S. Hu, X.-F. Zheng, and L. Pu, J. Org. Chem., 61, 5200 (1996).

23. S. Habaue, T. Seko, and Y. Okamoto, Macromolecules, 35, 2437 (2002).

24. G. Koeckelberghs, S. Sioncke, T. Verbiest, I. V. Severen, I. Picard, A. Persoons, and C. Samyn, Macromolecules, 36, 9736 (2003).

25. F. Kondo, D. Takahashi, H. Kimura, and M. Takeishi, Polym. J., 30, 161 (1998).

26. H. Kimura, D. Takahashi, T. Yamaguchi, and M. Takeishi, Sen-i Gakkaishi, 56, 169 (2000).

27. T. Takata, Y. Furusho, K. Murakawa, T. Endo, H. Matsuoka, T. Hirasa, J. Matsuo, and M. Sisido, J. Am. Chem. Soc., 120, 4530 (1998).

28. M. Teraguchi, Y. Horikawa, M. Kumata, T. Kaneko, and T. Aoki, Polym. Prepr., Jpn., 53, 2928 (2004). 
29. K. Maeyama, K. Ogura, A. Okamomo, K. Sakurai, Y. Yoshida, K. Ogino, and N. Yonezawa, Synth. Commun., 34, 3243 (2004).

30. P. E. Eaton and G. R. Carlson, J. Org. Chem., 38, 4071
(1973).

31. K. Maeyama, I. Hikiji, K. Ogura, A. Okamoto, K. Ogino, H. Saito, and N. Yonezawa, Polym. J., 37, 707 (2005). 